\title{
Measuring Entrepreneurial Readiness among Youth in Pakistan through Theory of Planned Behavior (TPB) Based Approach
}

\author{
Salman Zulfiqar \\ School of Public Affairs, University of Science and Technology China \\ Fahad Asmi \\ School of Public Affairs, University of Science and Technology China \\ Khurram Ejaz Chandia \\ School of Public Affairs, University of Science and Technology China
}

Binesh Sarwar

School of Public Affairs, University of Science and Technology China

Saira Aziz

School of Management Science, University of Science and Technology China

Received: February 3, 2017 Accepted: March 10, 2017

doi:10.5296/ber.v7i1.11037

URL: https://doi.org/10.5296/ber.v7i1.11037

\begin{abstract}
Purpose: The purpose of this paper is to measure entrepreneurial readiness among youth in Pakistan, through TPB based approach.

Design/Methodology/Approach: The data were collected from people who work in different fields like banking sector and education sector of Pakistan. In total 380 questionnaires were circulated among people through the online survey. The IBM Statistics SPSS 23.0 was used to perform statistical analysis.
\end{abstract}


Findings: The research finds that entrepreneurial attitude, social norms and perceived behavioral control have significant positive effect on entrepreneurial readiness among youngsters. Moreover, research shows that entrepreneurial knowledge has significant positive impact on entrepreneurial attitude, social norm and perceived social norm

Research Limitations: Research population is the main limitation in this research, small sample size was selected and results were compiled on the basis of this sample size.

Originality/value: In these existing economic crises of Pakistan, "Developing Entrepreneurs" is one of the important ways to boost financial growth. Youngsters always play an important role in the development of economy and have potential to become future entrepreneurs. Research to check readiness among youngsters to become entrepreneurs in Pakistan is limited. This research has added value in both theory and practice by identifying the factors that can develop students' intentions to become entrepreneurs.

Keywords: Entrepreneurial Readiness, Perceived Behavioral Control, Entrepreneurial Attitude, Social Norms, Entrepreneurial attitude, Theory of Planned Behavior

\section{Introduction}

Entrepreneurs plays vital role in growth of national income while increasing per capital income. Entrepreneurs' keeps the economic cycle running in equilibrium because, in order to run their businesses, they invest in products and services, which lead to the circulation of money in the economy. In order to run their business's operation, work force is needed, which helps in reducing unemployment in the society (Schumpeter, 1989). Entrepreneurs also provide economy with skilled and hardworking labor, which further leads to creativity and innovation. Entrepreneurs bring innovation and creativity in the product, which leads to more customer friendly products and services. Entrepreneurs are the ones, who use their resources effectively and efficiently in order to bring the prices of the products at affordable price that consumers can purchase (Gürol \& Atsan 2006). Entrepreneur is an uncertain decision maker and an innovator, has the ability to produce new product and services in order to gain profits (Hong et al. 2012). Entrepreneurs are good in making networks and learn from others, believes in himself/herself, take risk, does the research and evaluates the situation and takes decision(Ismail \& Zain 2015).

Pakistan is a developing country; not considerable attention was given to entrepreneurship. In the last few years' intention to become entrepreneur has raised.

This research paper use TPB model to evaluate that how entrepreneurial education changes behavior, attitude of people, which leads entrepreneurial start-ups. Entrepreneurial attitude, social norms and perceived behavioral control effect on entrepreneurial readiness among youngsters. And to find out does entrepreneurial knowledge has impact on entrepreneurial attitude, social norm and perceived social norm. According to (Tanveer et al. 2012) weak economic environment, uncertain market conditions, complex bank financing, high interest rate, lack of skills and expertise and lack of support from friends, family and government, are main factors, which discourage individuals to adopt entrepreneurship as career. Objective of this research is to find, how entrepreneurial education leads to change in entrepreneurial 
attitude, social norms and perceived behavioral control, which further leads to entrepreneurial intentions

\subsection{Aim of the Study}

The aim of this study is to understand the ground realities and the factors affecting the entrepreneurial readiness among youth. Specifically, the readiness will be measured on the basis of attitude, social norms (including superior and subjective aspects) and the Perceived Behavioral Control (PBC). The purpose is to highlight the emerging trend and future prospects, which can improve the youth's understanding and perceived value and benefits achieved by entrepreneurship.

\subsection{Literature Background}

Entrepreneurship has been considered as the key mechanism to achieve economic goals or growth. It is claimed by many researchers that entrepreneurship is a vehicle of economic development; entrepreneurship is directly proportional to the economic development. There are so many researchers, who are working on the topic, that entrepreneurship leads towards the growth of economy. Researchers like (Solow, 1956) \& (Swan, 1956) based their economic models of growth on neoclassical production function, which considers labor and capital the important factors of economic growth. As they provide economy with very skilled labor, which further leads to economic growth, as there is more and more skilled labor, people will be encouraged towards self-employment, which further leads to investing of capital in economy. According to (Schumpeter J. , 1934), entrepreneurs are able to generate economic shocks in economic cycle with the help of creativity and innovation process.

Many countries are facing high rate of unemployment among the graduate students. This unemployment can be reduced by introducing entrepreneurial courses, trainings and workshops; this could help youth in improving entrepreneurial skills (Wang \& Wong 2004). In early 1980s, a little number of students were inspired to start their own business but due to changes in macro environment, more students were inspired to become entrepreneurs in west (Scott \& Twomey, 1988). Self-employment rate increased from $7.4 \%$ in 1975 to $9.7 \%$ in 1990(Devine, 1994). World is facing challenges in the development of youth like unemployment, drug abuse, health, juvenile delinquency, hunger, wastage of time and resources(Kasim et al. 2014), (Geldhof et al. 2014), (Commission, 2012). Youth is facing shortage of entrepreneurial skills, lack of knowledge to financing new ventures, lack of knowledge about government and tax policies (Brixiov, Ncube, \& Bicaba, 2015). Education and training, entrepreneurship, youth internship programs, involvement of entrepreneurs in making policies regarding new venture encouragement in country, may help in youth development (Commission, 2012).

According to economists' point of view, people choose self-employment because of three major reasons earning, independence and unemployment (Taylor 1996). According to theories presented by (Blanchflower \& Oswald, 1991), when unemployment is at its peak and companies are not willing to pay, people prefer self employment instead, of wasting their time and energy in searching for work. The prosperity pull theory argued that when economy 
is going in positive direction and people know that they will get job, if they fail in their venture; people choose to start their own venture because they desire to be their boss, operate their own business idea and get the reward of their hardship(Barringer \& Ireland, 2010). Starting up or growth of new businesses in the developing countries is very difficult because of underdeveloped markets, and also all resources like financials, rules and regulation established by governments are being controlled by family businesses or feuds. Formal business activities and economic activities are being dominated by business groups in developing countries like Argentina, Brazil, Chile, India, Malaysia, Mexico, Nicaragua, Pakistan, South Korea, South Africa, Taiwan, and Turkey (Leff, 1978). Scholars and policy makers are fully convinced that entrepreneurship is the key driver of economic growth for both developing and developed countries. In recent times, developing countries are paying so much attention to entrepreneurship and innovation; there are a lot of opportunities for entrepreneurs because there are very few people, who are providing innovative and creative products and services to customers. Lack of staring-up cost and lack of skills are two major challenges, which entrepreneurs have to face, while starting-up a new venture (Brixiov et al. 2015).

\section{Entrepreneurial Knowledge}

Education is a source of knowledge, entrepreneurial education gave knowledge to youth in order to gain skills and create their own source of income through business or job. Entrepreneurial skills can be inherited but educational and training programs can reshape entrepreneurial skills. There are evidences that training and educational programs helps entrepreneurs in creating self-employment (Valerio, Parton, \& Robb, 2014). In developing countries private and government sectors are unable to provide wage jobs to every person; policy makers and scholars are seriously considering entrepreneurial education as potential that can help unemployed to gain skills and generate their own source of income (Gindling \& Newhouse, 2014). Entrepreneurial education is getting attention by universities across the world, in order to get competitive advantage and generate new sources of income. Institutions are focusing on new invention and knowledge, which further leads to creative and innovative ideas, which can be exploited by new ventures. Both, universities and governments are trying to build high tech and innovative science parks, where graduates and young entrepreneurs can innovate and economic growth boosts. For example, industries and governments have close link with MIT, Stanford and many other universities which encourage young graduate to become entrepreneurs (Jansen, Zande, Brinkkemper, \& Stam, 2015). Entrepreneurship not only helps in growth of economy but also helps in reducing unemployment. Developing countries like Malaysia, Indonesia, Sri Lanka and other ASEAN countries are facing growing graduate unemployment. Policy makers and scholars are seriously considering encouraging graduates to become entrepreneurs (Sondari, 2013).

The most important goal of entrepreneurial education is to develop entrepreneurial competencies among students and learners, which enhance the ability of entrepreneurs to successfully perform their business or job (Bird, Towards a theory of entrepreneurial competency, 1995)(Man T. , 2006)(S.Mitchelmore \& Rowley, 2010)(Rasmussen \& Wright, 2011)(Sanchez, 2011)(Man, Chan, \& Lau, 2002). In this globalized world, highly skilled 
human resource is the driving force of national development. Entrepreneurial education is just like, preparing youth for global challenges, which one is going to face, while doing business (Abereijo, 2015).

\section{Entrepreneurial Intention}

Intention is a cognitive depiction of an individual. (Kolvereid, 1996) defines intentions as an individual's predisposition to act something. (Bird \& Jelinek, The operation of entrepreneurial intentions, 1998) are pioneer researchers in the arena of entrepreneurship, who used the concept of intention to see the impact of intentions on entrepreneurship. According to (Bird \& Jelinek, The operation of entrepreneurial intentions, 1998), intentionality can be defined as: "A state of mind, leading attention, experience, and actions towards a specific goal (object) or pathway to its achievement". A number of empirical studies have found that an individual's intentions to become an entrepreneur predict his/her actual behavior to become an entrepreneur in future (Delmar \& Davidsson, 2000) \& (Krueger, Reilly, \& A.LCarsrud, 2000).

Researchers usually trace entrepreneurial intentions to three factors (Krueger et al., 2000). (Ajzen, The theory of planned behavior, 1991) also determined three elements of intention, which became very famous and future researchers have studied these three determinants of intention with respect to entrepreneurial intentions. The three elements of intentions have been named as attitude towards behavior, norms, and perceived behavioral control. (Ajzen, The theory of planned behavior, 1991) identified these elements of intention by observation and experience. ( $\mathrm{Jr}$ et al. 2007) support one of the drivers of intention identified by (Ajzen, The theory of planned behavior, 1991) that is attitude towards behaviour. According to (Engle \& Wolff 2010) the behavioral intention necessitates some antecedents particular to some targeted behavior.

On the basis of some previous researches, (Engle \& Wolff 2010) connected achievement motivation, autonomy and personal wealth to entrepreneurial intention as the antecedent of "attitude towards behaviour". The second antecedent of intention is subjective norm. (Ajzen, The theory of planned behavior, 1991) describes this construct as "the likelihood that important referent individual or groups approve or disapprove of executing some given behavior or action". According to (Ajzen, The theory of planned behavior, 1991), third antecedent of intention is Perceived Behavioral Control(PBC). PBC can be defined as the degree to which one identifies his/her capability or ability to successfully handle the situation. Researchers in this field have found that a person's behavior is highly influenced by the confidence level, one uses in one's ability to perform a successful behavior or action (Bandura, Reese, \& Adams, 1982)(Jr et al. 2007).

\section{Entrepreneurial Attitude}

Attitude is defined as psychological tendency of a person to express after evaluating particular entity with some degree of favor or disfavor (Kinicki \& Krietner, 2009). According to (Harjer \& Habib, 2013) attitude is positve or negative emotional reaction of a person's feeling and learning after gaining experience with object, activity or an idea. It is very 
important to learn about attitude because strong attitude would effect bahavior of a person (Zimmerman, 2008). Expectations held by individuals on the basis of beliefs about situation, object or event either positive or negative is called attitude; this attitude is further translated into intention and consequently, behavior towards situation, object or event (Ajzen \& Fishbein, 1980). Entrepreneurial training and educational programs are designed to influence the attitudes and values of individuals towards entrepreneurship, either adopt entrepreneurship as a career or to appriciate the role of entrepreneurs in society (Mwasalwiba 2012). Eduaction or knowledege is important to create awareness among individuals, in order to change attitude, which further leads to the change in behavior. (Martin, McNally, \& Kay, 2013)did extensive meta analysis on entrepreneurial education outcomes, which shows positive correlation between entrepreneurial education and attitude of people towards entrepreneurial venture. Entrepreneurial intention is a bi-product of one's self efficacy, attitude and the subjective norms toward entrepreneurial behavior (Krueger et al. 2000). Entrepreneurial education is the key to raise knowledge and skills which builts up attitude and self efficacy towards starting a new venture. As discussed in the literature of 'Education' and 'Attitude', the relevant hypotheses for the current study are following:

H1: The entrepreneurial attitude has a positive significant role in developing entrepreneurial intention among youngster.

H2: Access to entrepreneurial knowledge build positive impact on entrepreneurial attitude among youngsters.

\section{Social Norm}

Social norms direct one's social and political life, embedded norms are very strong and powerful because it affects behavior of one's in a given environment. Social norms are unwritten rules and regulation which are embedded within a group and these groups are expected to shape their behavior according to certain rules and regulation. Social norms should be shared by others and sustained by society's approval (Elster, 1989)\&(Kandori, 1992). Social norms are maintained by unwanted emotions like guilt, shame, cut from community and embarrassment, if one breaks those rules (Baumeister \& Leary, 1995). Social norms, beliefs and values have impacted on entrepreneurial activities; these factors have influenced on studying entrepreneurial research test, in order to measure entrepreneurial activity ((Becker \& Woessmann, 2009) \& (Urbano \& Alvarez, Institutional dimensions and entrepreneurial activity: An international study, 2014) \& (Aparicio et al. 2015). According to(Kautonen \& Tornikoski, 2010), society with high uncertainty avoidance, there is a fear of losing and competition; people merely adopt entrepreneurial career and startup activities. (Shane, 1993) institutes that there is a negative relationship between uncertain avoidance and innovation in the society. (Yordanova \& Tarrazon, 2010) states that there is negative relationship between societal uncertainty avoidance and individual risk taking (Kautonen \& Tornikoski, 2010). As discussed above, in 'Social Norm' and 'Entrepreneurial intention', the relevant hypotheses for the current study are given below:

H3: Social norm has a strong relationship with intention to become entrepreneurs among the youngster 
H4: Excess to Entrepreneurial knowledge builds positive impact on Social norm of entrepreneurship

\section{Perceived Behavioural Control}

Perceived behavioral control (PBC) is the degree to which an individual controls the opinions or views about the activity being studied that is entrepreneurship (Solesvik et al. 2012). (Icek Ajzen 2002)stated that the perceived control element of PBC holds individual's beliefs or opinions about themselves that they have a complete control over their behaviors or actions, that performance or non-performance of any task is solely dependent on them. This phenomenon is further explained by the two types of item: (a) with respect to perceived control over behavioral performance that is how much one believes that he/she has a control over performing some particular task. (b) With respect to what appears to us, as a locus of control (Rotter, 1966) \& (Conner \& Armitage, 1998). Several previous researches have stated PBC as an antecedent of intension. (Tsordia \& Candidate 2015) proved the impact of attitude towards behavior and PBC in the creation of entrepreneurial intention. Similar results have also been described by some other researchers like (Kolvereid, 1996)(Tkachev \& Kolvereid, 1999) \& (Ajzen, The theory of planned behavior, 1991). (Engle \& Wolff 2010) in their study found that $\mathrm{PBC}$ is a predictor of entrepreneurial intent. (Ajzen, The theory of planned behavior, 1991) states that PBC and self-efficacy are the similar phenomenon. According to(Krueger et al. 2000) PBC or self-efficacy is the antecedent of intention and individual's self-efficacy has been found to significantly influence the entrepreneurial behavior, and also improving the perceived likelihood of certain ways of action as important to encourage increased entrepreneurial intentions. As discussed in the literature of 'PBC' and Entrepreneurial Intention', the relevant hypotheses for the current study are following:

H5: Perceived behavioural control has positive significant role in developing entrepreneurial intention among youngsters

H6: Presence of entrepreneurial knowledge builds positive impact on PBC among youngsters

\section{Model Adopted for Study}

Theory of Planned Behavior (TPB), is multi-dimensional model, which is used in different fields, in order to analyze or interpret research result i.e. transport research (Chen 2016), social and behavioral science (Kim 2014), medical information (Hsieh 2015) science of total environment (Deng et al. 2016), ecological economics (Litvine et al. 2014), applied development psychology (Hawley \& Williford 2015), computer research (Liao et al. 2007) food quality and preferences (Lorenz et al. 2015) and in many other fields researchers are using this model. Theory of Planned Behavior (TPB) is wildly used in research to measure the intention of individual. TPB was presented by (Ajzen, 1991), theory argues that individual intention is the classification of three constructs attitude, subjective norms, perceived control behavior (self-efficacy). In this paper TPB is used to measure how person attitude leads his behavior towards entrepreneurial intention; subjective norms which involve social pressure from family, friends and other people in society affect individual behavior towards entrepreneurial activities; is perceived control behavior has some affect on individual 
behavior towards entrepreneurial activity.

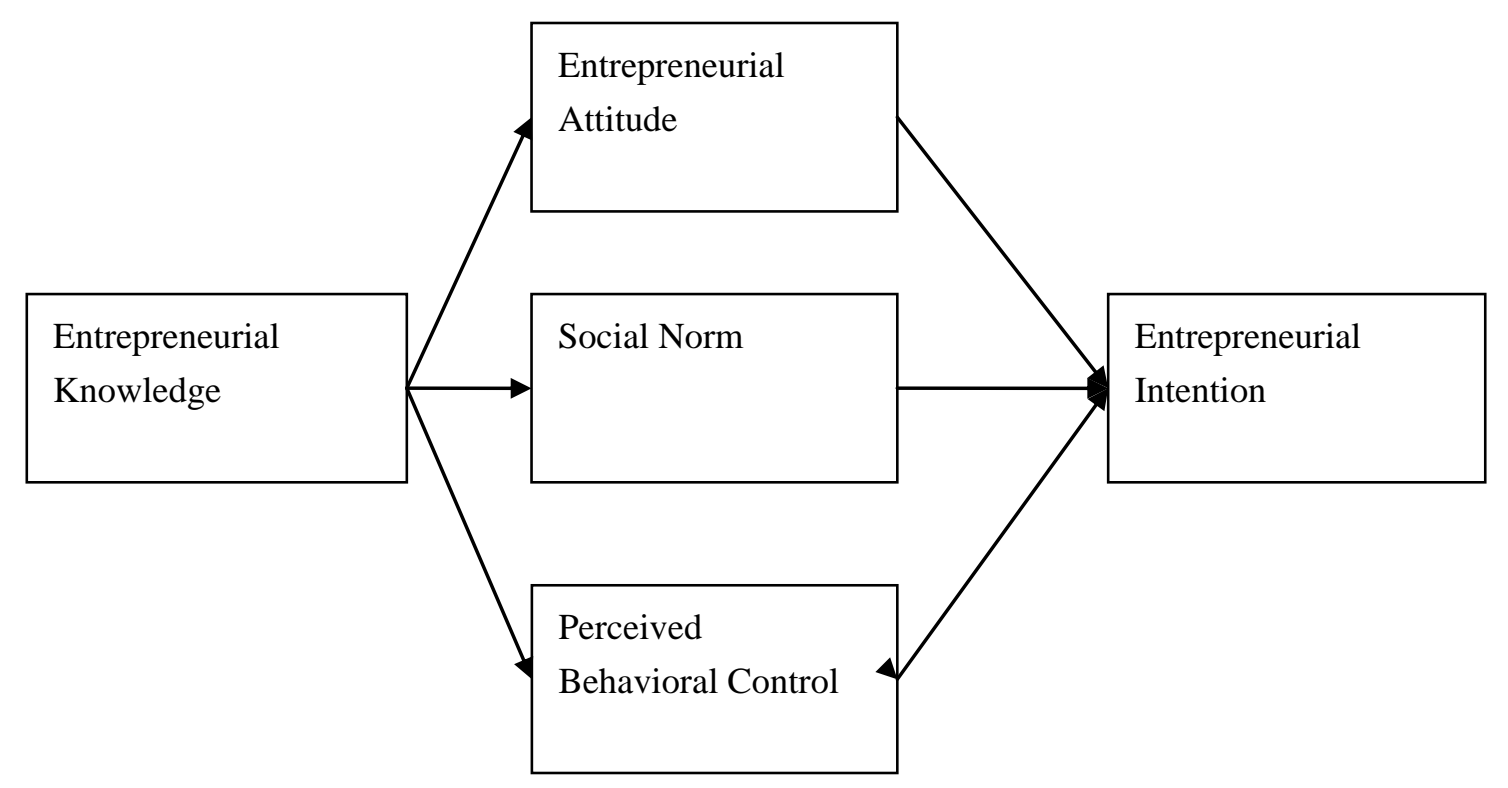

H1: The Entrepreneurial Attitude has a positive significant role in developing entrepreneurial intention among youngster

H2: Excess to Entrepreneurial knowledge built positive impact on entrepreneurial attitude among youngsters

H3: Social norm has a strong relationship with intention to become entrepreneurs among the youngster

H4: Excess to Entrepreneurial knowledge builds positive impact on Social norm of entrepreneurship

H5: Perceived Behavioral Control has positive significant role in developing entrepreneurial intention among youngsters

H6: Presence to Entrepreneurial knowledge builds positive impact on PBC among youngsters

\section{Methodology}

The current study adopted the quantitative approach to analyse entrepreneurial readiness among youth. Specifically, the self-administrated questionnaire was circulated in the target audience. The matrices of scale were adopted from the existing pool of literature as it increases the validity and credibility of the instruments used in the current study. To get the deep insight, the questionnaire comprised of demographics- related questionnaire as it helps to create the profile of the studied audience. In the further sections of the questionnaire, the questions regarding the Independent and dependent variables were used to improve the understanding and support the hypothetical model in the current study. 


\section{Ml Macrothink}

Business and Economic Research

ISSN 2162-4860

2017, Vol. 7, No. 1

The Likert scale based instrument of scale usually helps to understand the behavioral analysis. In the current study, the 7 points Likert scale used where the value of 1 (Strongly Disagree) to the value of 7 (Strongly Agreed) was ranged. The questionnaire was designed to understand the behavior of youth in Pakistan regarding their entrepreneurial knowledge, attitude, social norms, perceived behavioral control and the intentions. In other words, it helps to understand the entrepreneurial readiness among youth in the emerging and developing countries like Pakistan. Moreover, the validity of the scale and pilot test was performed in the initial phase of the current study.

\section{Sample and Data Collection}

The current study majorly focused the youth younger than the age of 30 . The targeted audience represented the individuals having professional education in the specialized academic disciplines or having the practical exposure of the competitive professional market, in other words, the individuals who have more chances to be entrepreneur in the competitive economic world. Almost 380 questionnaires were circulated, however only 311 were received as completed and valid for the further study and analysis. Specifically, the response rate of $81.85 \%$ was recorded.

In the beginning the demographics were analyzed as mentioned in the table below. Specifically, the recorded percentage of Male (58.13\%) and female (41.87\%) was observed. Most of the respondents were from the age group of 18-30, and the 281 respondents were holding the professional degree.

\begin{tabular}{lcc}
\hline Demographics & Frequency & Percentage \\
\hline Gender & & \\
Male & 211 & 58.13 \\
Female & 152 & 41.87 \\
Age Group & & \\
$18-21$ & 82 & 22.59 \\
$22-26$ & 95 & 26.17 \\
$27-30$ & 186 & 51.23 \\
Educational Level & & \\
Under-Graduate & 82 & 22.59 \\
Graduate & 155 & 42.70 \\
Post- Graduate & 126 & 34.71 \\
\hline
\end{tabular}

The population of COMSATS Institute of Information Technology, Sahiwal Campus (CIIT), Askari Bank Center point Lahore Branch, software houses in Technology Park Arfa Karim Center is approximately 6672. For the purpose of research, Cochran sampling formula is applied with 95 percent confidence level(Israel 2013). Total size of statistical sample is 363, which is calculated through following Cochran formula:

$$
n=\frac{6672 \times(1.96)^{2} \times(0.5) \times(0.5)}{(.05)^{2} \times 6672+(1.96)^{2} \times(0.5) \times(0.5)}=363
$$


Data was collected from both male and female, in order to deeply understand, whether there is any effect of gender on entrepreneurial activities. Total number of questionnaire floated were 400, out of which 255 questionnaires were filled by CIIT students, 125 questionnaires were filled by technology park software houses employees. Educational institutes, bank and software houses were selected, because, here the potential of becoming entrepreneur is high. The scale and questionnaire was adapted from (Solesvik et al. 2012).

\section{Findings and Analysis}

\subsection{Reliability and Validity Test}

Reliability of data is measured through Cronbach Aplha; in order to meet reliability criteria, Cronbach Alpha should be equal to or more then 0.70. The value of Cronbach alpha for Entrepreneurial Knowledge is 0.933, Entrepreneurial Attitude is 0.936, Social Norms is 0.871, Entrepreneurial Intention is 0.841 , and PBC is 0.792 . All the values are greater than 0.70 , which shows that all variables meet the reliability criteria.

\subsection{Descriptive Statistics}

Mean value for Entrepreneurial Knowledge is 4.7622, with standard deviation 1.726. Mean value for entrepreneurial attitude, is 5.22, with standard deviation 1.619, entrepreneurial attitude, Mean value for Social norms is 4.303 with standard deviation 1.852, Mean value for entrepreneurial intention is 4.653 with standard deviation 1.738. Mean value for PBC is 4.866 , with standard deviation 1.561 .

Table 1. Cronbach Alpha and Descriptive Statistical Test

\begin{tabular}{lcll}
\hline Variables & Cronbach Aplha & \multicolumn{2}{l}{ Descriptive Statistical Tests } \\
& Reliability Test & Mean & Standard Deviation \\
\hline Entrepreneurial Knowledge & 0.933 & 4.7622 & 1.726 \\
Entrepreneurial Attitude & 0.936 & 5.22 & 1.619 \\
Social Norms & 0.871 & 4.303 & 1.852 \\
Entrepreneurial Intention & 0.841 & 4.653 & 1.738 \\
Perceived Behavior control (PBC) & 0.792 & 4.866 & 1.561 \\
\hline
\end{tabular}

\subsection{Correlation Test}

Correlation Test was applied and the results show that all the variables are positively correlated with each other and their correlation values ranges from 0.467 to 0.770 . The benchmark value for correlation coefficient ranges between -1 and +1 . The values near to +1 represent strong positive correlation between the variables, while values of correlation coefficient near to or equal to -1 represents strong negative correlation between variables. There is strong positive correlation between entrepreneurial knowledge and entrepreneurial attitude, which is 0.770 then there is a moderate positive correlation between entrepreneurial attitude and Entrepreneurial intention and perceived control behavior i.e. 0.675 and 0.692 respectively. There is moderate positive correlation between entrepreneurial knowledge and social norm, entrepreneurial intention and $\mathrm{PBC}$ i.e. $0.539,0.580$ and 0.550 respectively. There is a weak correlation between social norm and PBC which is 0.467 shown in Table 2 
Table 2. Correlation Analysis

\begin{tabular}{lclcll}
\hline $\begin{array}{l}\text { Correlation of the } \\
\text { Dependent Variable } \\
\text { with the Independent }\end{array}$ & $\begin{array}{l}\text { Entrepreneurial } \\
\text { Education }\end{array}$ & $\begin{array}{l}\text { Entrepreneurial } \\
\text { Attitude }\end{array}$ & Social-Norm & $\begin{array}{l}\text { Entrepreneurial } \\
\text { intention }\end{array}$ & $\begin{array}{l}\text { Perceived } \\
\text { Behavioral } \\
\text { Control }\end{array}$ \\
\hline $\begin{array}{l}\text { Entrepreneurial } \\
\text { Education }\end{array}$ & 1 & & & & \\
$\begin{array}{l}\text { Entrepreneurial } \\
\text { Attitude }\end{array}$ & $.770^{* *}$ & 1 & & & \\
$\begin{array}{l}\text { Social-Norm } \\
\text { Entrepreneurial }\end{array}$ & $.539^{* *}$ & $589^{* *}$ & 1 & & \\
intention & $.580^{* *}$ & $.675^{* *}$ & $.550^{* *}$ & & \\
Perceived Behavioral & $.550^{* *}$ & $.692^{* *}$ & & & \\
\hline
\end{tabular}

10.4 Regression Analysis

The impact of entrepreneurial attention, social norms and perceived behavioral control on intention to become entrepreneurs was analyzed through multiple regression analysis. Overall model is significant, with $F$ test value of 43.453. F test is used to determine overall fitness of model, here $\mathrm{F}$ statistics overall significance of independent variables as part of regression model. Here F-statistic i.e. 43.453 is greater than F-critical, so it could be concluded that model is fit. $R^{2}$ shows, how much change in dependent variable is explained by independent variables. The regular coefficient of determination $R^{2}$ is again the measure of closeness of fit in multiple regression models. Here change in entrepreneurial intention due to Entrepreneurial attitude, social norms and perceived behavioural control is 0.515 . Here 0.551 units of change in entrepreneurial intention is explained through this i.e. entrepreneurial attitude, social norm and perceived behavioral control. Results are shown in table 3

Table 3. Model Analysis

\begin{tabular}{lcccc}
\hline Model & $\mathrm{R}$ & $R^{2}$ & $R^{2}$ & Std. Error of the Estimate \\
1 & $.717^{\text {aa }}$ & .515 & .503 & 1.22590 \\
Predictor ${ }^{\mathrm{a}}$ : (constant) & Entrepreneurial Attitude (EA), Social Norm (SN), PBC \\
\hline
\end{tabular}

\section{Regression Equation}

Calculation of individual impact of all factors on entrepreneurial intention to become entrepreneur is shown in table 3. A multiple regression was calculated to predict Entrepreneurial Intention to become entrepreneur is based on entrepreneurial attitude, social norm and perceived behavioural control. A significant regression equation was found ( $F$ $(3,123)=43.453, \mathrm{p}<.000)$, with $R^{2}$ of 0.503 , calculation were performed in table 4 , Regression equation is calculated as:

$$
y=\beta_{0}+\beta_{1} X_{1}+\beta_{2} X_{2}+\beta_{3} X_{3} \ldots \ldots \ldots+\beta_{n} X_{n}+\varepsilon
$$




$$
\mathrm{EI}=.386+.430(\mathrm{EA})+.201(\mathrm{SN})+.237(\mathrm{PBC})+.394
$$

All the values are calculated on 7 likert Scale to study the effect.H1 the Entrepreneurial Attitude has a positive significant role in developing entrepreneurial intention among youngsters is shown through $p=.000, \beta=0.430$ with standard error of 0.103 and $t$ value $=4.179$. $\mathrm{H} 2$ Social norm has a strong relationship with intention to become entrepreneurs among the youngster with $p=0.007, \beta=0.201$ with standard error of 0.073 and $\mathrm{t}$ value $=2.748$. H3 Perceived Behavioral Control has positive significant role in developing entrepreneurial intention among youngsters with $\mathrm{p}=0.016, \beta=0.237$ with standard error of 0.097 and $\mathrm{t}$ value $=2.443 \mathrm{t}$-value should be equal. Calculation are shown in Table 5

Table 4. ANOVA

\begin{tabular}{llllll}
\hline Model & Sum of Square & df & Mean Square & F & Significance \\
\hline Regression & 195.909 & 3 & 65.303 & 43.453 & $.000^{\mathrm{b}}$ \\
Residual & 184.847 & 123 & 1.503 & & \\
Total & 380.756 & 126 & & & \\
\hline
\end{tabular}

Note: ${ }^{a}$ Dependent Variable: Entrepreneurial Intention b Predictors (Constant) Entrepreneurial Attitude (EA), Social Norm (SN), PBC

Table 5. Regression Analysis

\begin{tabular}{llllll}
\hline $\begin{array}{l}\text { Standardized Coefficients for } \\
\text { the Independent Variables }\end{array}$ & $\beta$ & $\begin{array}{l}\text { Un-standardized } \\
\text { Coefficients } \\
\text { Standard Error }\end{array}$ & $\begin{array}{l}\text { Standardized } \\
\text { Coefficients Beta }\end{array}$ & T & Sig \\
\hline (Constant) & .386 & .394 & & .979 & .330 \\
Entrepreneurial Attitude & .430 & .103 & .400 & 4.179 & .000 \\
Social-Norm & .201 & .073 & .215 & 2.748 & .007 \\
Perceived Behavioral & .237 & .097 & .214 & 2.443 & .016 \\
Control & & & & & \\
\hline
\end{tabular}

Note: Dependent variable Entrepreneurial Intention

A multiple regression was used to predict Entrepreneurial attitude which is based on access to Entrepreneurial knowledge. A significant regression equation was found $(\mathrm{F}(1,125)=181.530$, $\mathrm{p}<.000)$, with $R^{2}$ of 0.592 .

Entrepreneurial Attitude $=1.791+0.770($ Entrepreneurial knowledge $)$

All the values are calculated on 7 Likert Scale to study the effect. H4 excess to knowledge build positive impact on entrepreneurial attitude among youngsters with $p=.000, \beta=.722$ with standard error of .054 and $t$ value $=13.473$. Calculations are shown in Table 6 . 


\section{Mll Macrothink}

Business and Economic Research

ISSN 2162-4860

2017, Vol. 7, No. 1

Table 6. Regression Analysis

\begin{tabular}{lllllll}
\hline $\begin{array}{l}\text { Standardized } \\
\text { for the } \\
\text { Variables }\end{array}$ & $\begin{array}{c}\text { Coefficients } \\
\text { Independent }\end{array}$ & $\beta$ & $\begin{array}{l}\text { Un-standardized } \\
\text { Coefficients } \\
\text { Standard Error }\end{array}$ & $\begin{array}{l}\text { Standardized } \\
\text { Coefficients Beta }\end{array}$ & T & Sig \\
\hline (Constant) & 1.791 & .271 & & 6.604 & .330 \\
Entrepreneurial Knowledge & .722 & .054 & .770 & 13.473 & .000 \\
\hline
\end{tabular}

Note: Dependent variable Entrepreneurial Attitude

A multiple regression was estimated to predict Social Norms towards entrepreneurship is based on excess to entrepreneurial Knowledge. A significant regression equation was found $(\mathrm{F}(1,125)=51.068, \mathrm{p}<.000)$, with $R^{2}$ of 0.290 .

\section{Social Norm $=1.550+0.539$ (entrepreneurial knowledge)}

All the values are calculated on 7 Likert Scale to study the effect. H5 excess to Entrepreneurial knowledge build positive impact on Social Norm of entrepreneurship among youngsters with $p=.000, \beta=0.578$ with standard error of .410 and $t$ value $=7.146$ is accepted.

Calculation are shown in Table 7.

Table 7. Regression Analysis

\begin{tabular}{llllll}
\hline $\begin{array}{l}\text { Standardized Coefficients for } \\
\text { the Independent Variables }\end{array}$ & $\beta$ & $\begin{array}{l}\text { Un-standardized } \\
\text { Coefficients } \\
\text { Standard Error }\end{array}$ & $\begin{array}{l}\text { Standardized } \\
\text { Coefficients Beta }\end{array}$ & T & Sig \\
\hline (Constant) & 1.550 & .410 & & 3.786 & .000 \\
Entrepreneurial Knowledge & .578 & .081 & .539 & 7.146 & .000 \\
\hline
\end{tabular}

Note: Dependent Variable Social Norm

A multiple regression was estimated to predict perceived Behavioral control is based on presence of entrepreneurial knowledge. A significant regression equation was found $(\mathrm{F}(1,125)$

$=54.330, \mathrm{p}<.000)$, with $R^{2}$ of 0.303 .

$$
\mathrm{PBC}=2.487+0.550 \text { (entrepreneurial knowledge) }
$$

All the values are calculated on 7 Likert Scale to study the effect. H6 presence to knowledge build positive impact on PBC among youngsters with $p=.000, \beta=.499$ with standard error of 0.343 and $t$ value $=7.371$ is accepted Calculation are shown in Table 8 . 
Table 8. Regression Analysis

\begin{tabular}{llllll}
\hline $\begin{array}{l}\text { Standardized Coefficients for } \\
\text { the Independent Variables }\end{array}$ & $\beta$ & $\begin{array}{l}\text { Un-standardized } \\
\text { Coefficients } \\
\text { Standard Error }\end{array}$ & $\begin{array}{l}\text { Standardized } \\
\text { Coefficients Beta }\end{array}$ & T & Sig \\
\hline (Constant) & 2.487 & .343 & & 7.250 & .000 \\
Entrepreneurial Knowledge & .499 & .068 & .550 & 7.371 & .000 \\
\hline
\end{tabular}

Note: Dependent variable PBC

Through research it is clear that in creating Entrepreneurial Intention factors like entrepreneurial attitude, social norms and perceived behavioral control play their role by certain percentage like $40.0 \%, 21.5$ and $21.4 \%$ respectively. Through quantitative research it was found that $77 \%$ of the Entrepreneurial attitude can be built through entrepreneurial knowledge as entrepreneurial knowledge helps in creating in social norm by $53.9 \%$ and perceived behavioral control can be built by $55.0 \%$.

\section{Discussion and Future Studies}

According to (Sanchez2011 \& Burgoyne 1989), entrepreneurial knowledge changes attitude of youngsters and motivates them to perform entrepreneurial activities. Entrepreneurial knowledge is considered as potential that help unemployed to gain skills and generate their own source of income(Gindling \& Newhouse, 2014).Entrepreneurial educational training programs are designed to change attitudes and values of individuals towards entrepreneurship, either adopt entrepreneurship as a career or to appriciate the role of entrepreneurs in society(Mwasalwiba, 2012). According to (Martin, McNally, \& Kay, 2013) analysis on entrepreneurial education have positive correlation with attitude of people towards entrepreneurship venture.According to (Kautonen \& Tornikoski2010) high uncertainty avoidance in society, there is a fear of losing of capital and competition; people are reluctant to adopt entrepreneurial career. (Shane,1993). Yordanova \& Tarrazon (2010) stated a negative relation between societal uncertainty avoidance and individual risk taking. (Kautonen \& Tornikoski, 2010). Entrepreneurial studies are defined as knowledge, skills and attitude that motivate graduates to perform entrepreneurial jobs (Sanchez, 2011)(Burgoyne, 1989). Entrepreneurship is considered as one of the most important factors in economic growth throughout the world. In order to encourage entrepreneurs, university can play a vital role in supporting Research \& Development (R\&D) and teaching entrepreneurship to students (P.Davidsson, Low, \& Wright, 2001)(Haase \& Lautenschlager, 2011)(Elaine \& Gray, 2013). According to (Donckels, 1991), main purpose of entrepreneurial education is to create awarness of entrepreneurship among individuals, which further leads to change in attitude towards entrepreneurship

Entrepreneurs not only contribute to the development of economy but also help in developing societies. All the governments through the world are encouraging people to become entrepreneur and play their role in developing economy and society. Entrepreneurs' plays vital role in growth of national income by increasing per capita income but the situation in Pakistan is at its worse stage. Unemployment among youngsters is one of the major problems 
of Pakistan. As there is political, socio economics and socio environment crises due to which youngsters are unable to find jobs.

According to Global Entrepreneurship and Development Index (GEDI), Pakistan's GEDI is $18.7 \%$ and ranks at the bottom of Entrepreneurship ranking i.e. 115 out of 120 (Szerb \& Autio,(2014). Pakistan is a factor driven economy, where people buy and sell basic products and services, there are great opportunities for entrepreneurs to be successful as compared to innovative and efficiency based economy (Terjesen et al. 2012). Total Entrepreneurial Activities (TEA), which refers to percentage of working-age population, who are willing to engage themselves in entrepreneurial activities, TEA rate for Pakistan is $9.08 \%$, which is lower than the average rate of $11.7 \%$ of factor driven economies. According to report, the new business ownership percentage in Pakistan is $2.7 \%$, which is considerably low as compared to other factor driven economies $11.8 \%$. Entrepreneurial Attitude Index (EAI) is 14.9, which is lowest among 120 countries. Variables used to calculate EAI are start-up skills, risk acceptance, opportunities, networking and cultural support. Pakistan's probability of start-up skills is 0.07 , risk acceptance is 0.07 and cultural support 0.23 which is lowest among 120 countries just a head of Chad and Burundi (Szerb \& Autio 2014). Global Competitive Index (GCI) comprises of the functional institutes, polices and infrastructures, which affects the economic efficiency and labor market in the country. Primarily, the triggering forces for establishing resilient and concrete foundation of any economy includes intelligent macroeconomic environment analysis, health and primary education, agile financial market development and technological readiness. Macroeconomic environment and market size of Pakistan is showing a positive response but other factors like good market efficiency, labor market efficiency, financial market development, technological readiness, innovation and business sophistication are stagnant. Encouragement for entrepreneurship helps Pakistan in dealing with all declining factors.

\section{References}

Abereijo, I. (2015). Developing Entrepreneurial Competences in University Lecturers: Obafemi Awolowo University Experience. KJBM, 32-40.

Ajzen, I. (1991). The theory of planned behavior. Journal of Organizational Behavior and Human Decision Processes, 179-211.

Ajzen, I., \& Fishbein, M. (1980). Understanding attitudes and predicting social behavior. Englewood: Prentice Hall.

Bandura, A., Reese, L., \& Adams, N. E. (1982). Microanalysis of action and fear arousal as a function of differential levels of perceived self-efficacy. Journal of Personality and Social Psychology, 5, 5-21. https://doi.org/10.1037/0022-3514.43.1.5

Barringer, B. R., \& Ireland, R. D. (2010). Entrepreneurship: Successfully Launching New Ventures. London: Pearson.

Baumeister, R., \& Leary, M. (1995). The need to belong: desire for interpersonal attachments as a fundamental human motivation. Psychological Bulletin. 
https://doi.org/10.1037/0033-2909.117.3.497

Becker, S., \& Woessmann, L. (2009). Was weber wrong? A human capital theory of protestant economic history. Q. Journal Economic, 531-596.

https://doi.org/10.1162/qjec.2009.124.2.531

Bird, B. (1995). Towards a theory of entrepreneurial competency. Advances in Entrepreneurship, Firm Emergence and Growth, 51-72.

Bird, B., \& Jelinek, M. (1998). The operation of entrepreneurial intentions. Entrepreneurial Theory and pratice, 21-29.

Blanchflower, D., \& Oswald, A. (1991). whats Makes an Entrepreneur. institute of Economics and Statistics.

Briggs, S., \& Cheek, J. (1986). The role of factor analysis in the development and evaluation of personality scales. Journal of Personality, 106-148.

https://doi.org/10.1111/j.1467-6494.1986.tb00391.x

Burgoyne, J. (1989). Creating the managerial portfolio: building on competency approaches to management development. Management Learning, 56-61.

https://doi.org/10.1177/135050768902000109

Commission, E. (2012). Draft 2012 Joint Report of the Council and the Commission on the implementation of the renewed framework for European cooperation in the youth field (EU Youth Strategy(2010-2018). Brussels.

Conner, M., \& Armitage, C. J. (1998). Extending the theory of planned behavior: a review and avenues for further research. Journal of Applied Social Psychology, no. 15, 1429-1469. https://doi.org/10.1111/j.1559-1816.1998.tb01685.x

Davidsson, P., Low, M., \& Wright, M. (2001). Achievements and Future Directions for Entrepreneurship Research. Entrepreneurship Theory and Practice, 5-16.

Delmar, F., \& Davidsson, P. (2000). Where do they come from? Prevalence and characteristics of nascent entrepreneurs. Entrepreneurship and Regional Development, 12, 1-23. https://doi.org/10.1080/089856200283063

Devine, T. (1994). Characteristics of self-employed women in US. Labor review, 20-34.

Donckels, R. (1991). EDUCATION AND ENTREPRENEURSHIP EXPERIENCES FROM SECONDARY AND UNIVERSITY EDUCATION IN BELGIUM. Journal of Small Business \& Entrepreneurship, 35-42. https://doi.org/10.1080/08276331.1991.10600389

Elaine, R., \& Gray, D. (2013). Does Entrepreneurship Education Really Work? A Review and Methodological Critique of the EmpiricalLiterature on the Effects of University-Based Entrepreneurship Education. Journal of Small Business Management, 329-351.

Elster, J. (1989). Social norms and economic theory. Journal of Economic Perspectives, 99-117. https://doi.org/10.1257/jep.3.4.99 


\section{Macrothink}

Business and Economic Research ISSN 2162-4860 2017, Vol. 7, No. 1

Gindling, T., \& Newhouse. (2014). Self-employment in the developing world. NewYork: World development Bank.

Haase, A., \& Lautenschlager, A. (2011). The Teachability Dilemma of Entrepreneurship. International Entrepreneurship Management Journal, 145-162.

https://doi.org/10.1007/s11365-010-0150-3

Harjer, H., \& Habib, A. (2013). Factors of entrepreneurial intention of the public civil servant: empirical evidence in the case of Tunisia. nternational Journal of Business Management and Economic Research, 672-682. https://doi.org/10.1016/j.ijme.2015.03.001

Jansen, S., Zande, T. v., Brinkkemper, S., \& Stam, E. (2015). How education, stimulation, and incubation encourage student entrepreneurship: Observations from MIT, IIIT, and Utrecht University. The International Journal of Management Education.

https://doi.org/10.1016/j.ijme.2015.03.001

Kandori, M. (1992). Social norms and community enforcement. The Review of Economic Studies, 63-80. https://doi.org/10.2307/2297925

Kautonen, T., \& Tornikoski, S. L. (2010). Influence of work history on entrepreneurial intentions in prime age and third age: a preliminary study. International Small Business Journal, 583-601. https://doi.org/10.1177/0266242610368592

Kinicki, A., \& Krietner, R. (2009). The nature of attitudes, organizational behavior. eGraw Hill Companies Inc.

Kolvereid, L. (1996). "Prediction of employment status choice intentions. Entrepreneurship Theory and Practice, fall, 47-57.

Krueger, N., Reilly, M., \& A.LCarsrud. (2000). Competing models of entrepreneurial intentions. Journal of Business Venturing, 411-432.

https://doi.org/10.1016/S0883-9026(98)00033-0

Leff, N. (1978). Industrial organization and entrepreneurship in the developing countries: the economic groups. Economic Development and Cultural Change, 661-667.

https://doi.org/10.1086/451052

Loasby, B. (1982). The Entrepreneurship in Economic Theory. Journal of Political Economy.

Lumpkin, G. T., \& Dess, G. G. (1996). Clarifying the entrepreneurial orientation construct. . Academy of Management Review, 135-172.

Man, T. (2006). Exploring the behavioural patterns of entrepreneurial learning: a competency approach. Education plusTraining, (pp. 309-321).

Man, T. W., Chan, K., \& Lau, T. (2002). The competitiveness of small and medium enterprises: a conceptualization with focus on entrepreneurial competencies. Journal of Business Venturing, 123-142. https://doi.org/10.1016/S0883-9026(00)00058-6

Martin, B., McNally, J., \& Kay, M. (2013). Examining the formation of human capital in 
entrepreneurship: a meta-analysis of entrepreneurship education outcomes. Journal of Business Venturing, 211-224. https://doi.org/10.1016/j.jbusvent.2012.03.002

Mitchelmore, S., \& Rowley, J. (2010). Entrepreneurial competencies: a literature review and development agenda. International Journal of Entrepreneurial, 92-111.

Rasmussen, E., \& Wright, S. M. (2011). The evolution of entrepreneurial competencies: a longitudinal study of university spin-off venture emergence. Journal of Management Studies, 1314-1345. https://doi.org/10.1111/j.1467-6486.2010.00995.x

Rotter, J. (1966). Generalized expectancies for internal versus external control of reinforcemen. Psychological Monographs, 1, 80.

Sanchez, J. (2011). University training for entrepreneurial competencies: Its impact on intention of venture creation. International Entrepreneurship and Management Journal, 239-254. https://doi.org/10.1007/s11365-010-0156-х

Schumpeter. (1989). Economic Theory and Entrepreneurial History. Reprinted from Change and the Entrepreneur. New Brunswick: Transaction Publishers.

Schumpeter, J. (1934). The Theory of Economic Development: An Inquiry Into Profits, Capital, Credit, Interest, and the Business Cycle. transaction book.

Scott, M., \& Twomey, D. (1988). The long-term supply of entrepreneurs: students' career aspirations in relation to entrepreneurship. Journal of Small Business Management, 5-13.

Shane, S. (1993). Cultural influences on national rates of innovation. Journal of Business Venturing, 59e73.

Solow, R. (1956). A contribution to the theory of economic growth. Q.J Economic Record, 65-94.

Sondari, M. C. (2013). Is Entrepreneurship Education Really Needed ? : Examining the Antecedent of Entrepreneurial Career Intention. Indonesia International Conference on Innovation, Entrepreneurship and Small Business (pp. 44-53). Indonesia: Elsevier Ltd.

Swan, T. (1956). Economic growth and capital accumulation. Economic Record, 334-361. https://doi.org/10.1111/j.1475-4932.1956.tb00434.x

Tkachev, A., \& Kolvereid, L. (1999). Self-employment intentions among Russian students. Entrepreneurship and Regional Development, 11(3), 269-280. I

https://doi.org/10.1080/089856299283209

Urbano, D., \& Alvarez, C. (2014). Institutional dimensions and entrepreneurial activity: An international study. Small Business Economics , 2(42), 703-716.

https://doi.org/10.1007/s11187-013-9523-7

V. Rindova, Barry, D., \& Ketchen, J. (2009). Entrepreneuring as emancipation. Academy of Management Review, 477-491. https://doi.org/10.5465/AMR.2009.40632647

Valerio, A., Parton, B., \& Robb, A. (2014). Entrepreneurship education and training 
programs around the world: Dimensions for success. Washington D.C: World Bank. https://doi.org/10.1596/978-1-4648-0202-7

WEF. (2014). World Economic Forum. Retrieved 2014, from World Economic Forum: http://reports.weforum.org/global-competitiveness-report-2015-2016/economies/\#indexId=G $\mathrm{CI} \&$ economy $=\mathrm{PAK}$

Wiklund, J. (1999). The Sustainability of the Entrepreneurial Orientation-Performance Relationship. Entrepreneurship Theory and Practice, 141-155.

Yordanova, D., \& Tarrazon, M. (2010). Gender differences in entrepreneurial intentions:evidence from Bulgaria. Journal of Developmental Entrepreneurship, 245-261. https://doi.org/10.1142/S1084946710001543

Zimmerman, R. (2008). Understanding the impact of personality traits on individual's turnover decision. A metal analytical model. Journal of Personnel Psychology, 309-348. https://doi.org/10.1111/j.1744-6570.2008.00115.x

\section{Copyright Disclaimer}

Copyright for this article is retained by the author(s), with first publication rights granted to the journal.

This is an open-access article distributed under the terms and conditions of the Creative Commons Attribution license (http://creativecommons.org/licenses/by/3.0/). 